Sodium selenate was next mixed with sodium pyrophosphate. Much less time was required for the volatilization of the selenic acid than for that of the telluric acid. The temperature was gradually raised to $450^{\circ} \mathrm{C}$. It was not allowed, nor was it necessary, to go beyond this point.

ANALYSES.

\begin{tabular}{|c|c|c|c|}
\hline & $\begin{array}{l}\text { Phosphorus } \\
\text { present in the } \\
\mathrm{Na}_{2} \mathrm{P}_{2} \mathrm{O}_{7} \text { used. } \\
\text { Gram. }\end{array}$ & $\begin{array}{c}\text { Sodium } \\
\text { selenate. } \\
\text { Gram. }\end{array}$ & $\begin{array}{c}\text { Phosphorus } \\
\text { found as } \\
\mathrm{Mg}_{9} \mathrm{P}_{2} \mathrm{O}_{7} \\
\text { Gram. }\end{array}$ \\
\hline I & 0.0728 & o.I $76_{3}$ & 0.0729 \\
\hline 2 & 0.1057 & 0.2017 & 0.1054 \\
\hline 3 & 0.1198 & o.I4I 6 & O.II99 \\
\hline
\end{tabular}

The preceding results with phosphates and tellurates and those with selenates and phosphates leave no doubt as to the complete separation of their respective acids, in the manner indicated. The method is free from all disturbing factors and may be executed without difficulty.

[CONTRIBUTION FROM THE JOHN HARRISON LABORATORY OF CHEMISTRY, No. 45.]

\title{
THE PRECIPITATION OF COPPER BY ZINC.
}

BY JOHs C. Shengle AND EDGAR F. SMith.

Received August 2. 1899.

\begin{abstract}
$A T$ various times during the past year attempts have been A made in this laboratory to make a direct comparison between silver and cadmium, with the hope that in this way the atomic mass of the latter metal might be definitely established. The most carefully purified metallic cadmium in weighed amounts was allowed to act upon various soluble salts of silver. The precipitation of the latter metal was rapid and complete. The results while very fair in a quantitative respect could not be used for the purpose designed. The precipitated silver contained cadmium. It was not undissolved portions of the latter but metal originating from the salt which was acted upon, which salt became in some way encased in the silver so that the most painstaking efforts failed to eliminate it. Nor did it seem to make any difference as to which silver salt was acted upon. Cadmium, in small amounts it is true, but nevertheless, cadmium was invariably discovered in the beautiful deposits of silver.
\end{abstract}


When copper salts were substituted for silver salts, the cadmium threw out the copper quickly and in calculated amounts, but it also was contaminated with varying quantities of cadmium, so that the scheme originally planned for the determination of the atomic mass of cadmium was abandoned.

This negative experience suggested the idea of testing the copper precipitated by metallic zinc. This being a method recommended for the quantitative estimation of copper we concluded to ascertain if possible whether it carried or retained any zinc. Pure copper sulphate was prepared, and metallic zinc was also obtained pure by the distillation method of Morse and Burton. ${ }^{1}$

The determinations were conducted in the usual manner, but instead of weighing the precipitated copper it was dissolved in nitric acid and estimated by means of the electric current. The liquor poured off from this deposit was examined for the zinc.

\section{ANALYSES.}

I. Twenty cc. of a copper salt solution, containing o. I739 gram of copper, was precipitated by metallic zinc. The deposit of copper was filtered, thoroughly washed, dried, and dissolved in acid, and its solution electrolyzed, the filtrate from the copper deposit being used for the determination of any contaminating zinc:

\begin{tabular}{clc}
$\begin{array}{c}\text { Copper } \\
\text { present. } \\
\text { Gram. }\end{array}$ & $\begin{array}{c}\text { Copper } \\
\text { found. } \\
\text { Gram. }\end{array}$ & $\begin{array}{c}\text { Zinc } \\
\text { found. } \\
\text { Gram. }\end{array}$ \\
\hline$\ldots \ldots \ldots \ldots$ 0.I739 & 0.1742 & 0.0067
\end{tabular}

In the second and third determinations the results were:

$\begin{array}{rlc}\begin{array}{c}\text { Copper } \\ \text { present. } \\ \text { Gram. }\end{array} & \begin{array}{c}\text { Copper } \\ \text { found. } \\ \text { Gram. }\end{array} & \begin{array}{c}\text { Zinc } \\ \text { found. } \\ \text { Gram. }\end{array} \\ \text { II } \ldots \ldots \ldots \ldots 0.1739 & 0.174 \mathrm{I} & 0.0027 \\ \text { III } \ldots \ldots \ldots \ldots 0.2609 & 0.2612 & 0.0033\end{array}$

Twenty-two precipitations were made with varying conditions. Zinc was found in all of the precipitated copper. As a rule this method gives fair results, but it is notwithstanding interesting to know that the good results must be due largely to a balancing of errors.

1 Am. Chem. J., to, 148, (1888). 